\title{
HUBUNGAN PERSEPSI MAHASISWA SEMESTER IV TENTANG METODE PEMBELAJARAN SCL (STUDENT CENTER LEARNING)
}

TERHADAP IP (INDEKS PRESTASI)

\author{
${ }^{1}$ Jenny Oktarina \\ ${ }^{1}$ STIKes Borneo Cendekia Medika Pangkalan Bun \\ ${ }^{1}$ Email : oktarina.jenny@yahoo.co.id
}

\begin{abstract}
ABSTRAK
Student Center Learning (SCL) merupakan suatu paradigma baru yang terdapat dalam konsep pembelajaran yang berfokus pada pembelajar. Pada kenyataannya mahasiswa masih banyak mempunyai persepsi negatif tentang metode pembelajaran SCL (student centered learning). Tujuan penelitian ini adalah Menganalisa Hubungan Persepsi Mahasiswa Semester IV Tentang Metode Pembelajaran SCL (Student center learning) Terhadap IP (Indeks Prestasi). Jenis penelitian adalah penelitian analitik dengan pendekatan waktu cross sectional. Populasi sebanyak 54 mahasiswa dengan sampel 48 mahasiswa menggunakan teknik sampling probability sampling, tipe random sampling. Pengumpulan data dengan kuesioner dan data sekunder. Analisa data menggunakan uji chi square dengan $\alpha=0,05$. Hasil penelitian terhadap 48 mahasiswa, 25 (65,8\%) mahasiswa memiliki persepsi negatif dan IP kurang memuaskan, sedangkan 2 (20\%) mahasiswa memilki persepsi positif dan IP memuaskan. Hasil uji statistik didapatkan tidak ada hubungan antara persepsi mahasiswa semester IV tentang metode pembelajaran SCL (student centered learning) terhadap IP (indeks prestasi) $(\mathrm{P}=0,472>\alpha=0,05)$. Kesimpulan mayoritas mahasiswa semester IV memiliki persepsi negatif tentang metode pembelajaran SCL, memiliki IP kurang memuaskan dan tidak ada hubungan antara persepsi mahasiswa semester IV tentang metode pembelajaran SCL (student centered learning) terhadap IP (indeks prestasi).
\end{abstract}

Kata kunci : persepsi, SCL (student center learning), IP (indeks prestasi)

\author{
RELATIONSHIP BETWEEN THE SEMESTER IV STUDENTS \\ 'PERCEPTION OF SCL (STUDENT CENTER LEARNING) LEARNING \\ METHODS AGAINST IP (ACHIEVEMENT INDEX)
}

\section{ABSTRACT}

Student Center Learning (SCL) is a new paradigm contained in the concept of learning that focuses on learners. In fact many students still have negative perceptions about the learning methods of SCL (student centered learning). The purpose of this study is to Analyze the Relationship of Semester IV Student 
Perceptions About Learning Methods SCL (Student center learning) Against IP (Achievement Index). This type of research is analytic research with cross sectional time approach. The population was 54 students with a sample of 48 students using a probability sampling technique, the type of random sampling. Data collection by questionnaire and secondary data. Data analysis using chi square test with $\alpha=$ 0.05. The results of the study of 48 students, 25 (65.8\%) students had negative perceptions and IPs were unsatisfactory, while 2 (20\%) students had positive perceptions and IPs were satisfactory. The results of the statistical test found no relationship between perceptions of fourth semester students about the learning methods of SCL (student centered learning) on IP (achievement index) $(P=0.472>$ $\alpha=0.05)$. Conclusion the majority of semester IV students have negative perceptions about the SCL learning method, have a less satisfactory IP and there is no relationship between the fourth semester students' perceptions about the SCL learning method (student centered learning) on IP (achievement index).

Keywords: perception, SCL (student center learning), IP (achievement index)

\section{PENDAHULUAN}

Student Center Learning (SCL) merupakan suatu paradigma baru yang terdapat dalam konsep pembelajaran yang berfokus pada pembelajar. Pada konsep ini dijelaskan bahwa pengajar dimungkinkan untuk membangun sendiri pengetahuannya, sehingga diharapkan mereka memperoleh pengetahuan mendalam yang akhirnya meningkatkan kualitas dari pembelajar itu sendiri. Ilmu pengetahuan dan teknologi (termasuk teknologi informasi) telah dan terus berkembang dengan pesatnya. (Soemantrie, 2007) Namun demikian masih terdapat kelambanan dalam penyesuaian terhadap perkembangan tadi, yaitu perubahan proses pembelajaran. Metode pembelajaran "I lecture, you listen" masih mewarnai pendidikan di Perguruan Tinggi. Dosen merupakan tokoh sentral, dan kurang lebih $80 \%$ waktunya digunakan untuk memindahkan (transfer) ilmunya secara konvensional (one way traffic), sementara itu para peserta didik duduk mendengarkan ceramahnya dengan aktivitas minimal tanpa mengaktifkan prior knowledge mereka yang relevan dengan pokok bahasan. Di dalam one way traffic method para peserta didik menunjukkan sikap apatis dan tidak tertarik terhadap proses pembelajaran. Lebih dari itu, kemampuan konseptualisasi sebagian besar peserta didik bersifat terbatas karena mereka belajar dalam struktur dan pengarahan yang kaku. Mereka tidak dapat think outside the box (berpikir di luar pakem). Perubahan paradigma dalam proses pembelajaran yang tadinya berpusat pada dosen menjadi pembelajaran yang berpusat pada mahasiswa diharapkan dapat mendorong mahasiswa untuk terlibat secara aktif dalam membangun pengetahuan, sikap dan perilaku. Melalui proses pembelajaran dengan keterlibatan aktif mahasiswa ini 
berarti dosen tidak mengambil hak anak untuk belajar dalam arti yang sesungguhnya. Dalam proses SCL, maka mahasiswa memperoleh kesempatan dan fasilitas untuk membangun sendiri pengetahuannya sehingga mereka akan memperoleh pemahaman yang mendalam, dan pada akhirnya dapat meningkatkan mutu kualitas mahasiswa.

Perubahan-perubahan mendasar pendidikan tinggi yang mendunia tersebut juga mempengaruhi pembaharuan konsep kurikulum pendidikan tinggi yang dituangkan dalam Kepmendiknas No. 232/U/2000 dan No. 045/U/2002. Hal ini berdampak pada perubahan paradigma dalam proses pembelajaran yang awalnya Teacher Centered Learning (TCL) menjadi Student Centered Learning (SCL). Konsekuensi dari paradigma baru ini adalah pengajar berperan sebagai fasilitator dan motivator dengan menyediakan beberapa strategi belajar yang memungkinkan. mahasiswa (bersama dosen) memilih, menemukan dan menyusun pengetahuan serta cara mengembangkan ketrampilannya (method of inquiry and discovery). HELTS 2003-2010 yang dikeluarkan Ditjen Dikti bulan April 2003 memberi amanah yang salah satunya adalah penerapan prinsip Student Centered Learning (SCL) dalam proses pembelajaran. Pada saat ini ada dua model pembelajaran pada perguruan tinggi yaitu Teacher Centered Learning (TCL) dan Student Centered Learning (SCL). Model pembelajaran yang dianut pada perguruan tinggi mulai mengalami perubahan yakni dari bentuk Teacher Centered Learning (TCL) ke Student Centered Learning (SCL). Faktor pertama yang mendukung perubahan model pembelajaran di perguruan tinggi tersebut dikarenakan adanya perubahan secara global meliputi persaingan yang semakin ketat diikuti dengan perubahan orientasi lembaga pendidikan, yakni perubahan persyaratan kerja. Faktor kedua karena adanya masalah yang semakin kompleks sehingga perlu disiapkan lulusan yang mempunyai kemampuan di luar bidang studinya. Faktor ketiga karena perubahan cepat di segala bidang kehidupan sehingga diperlukan kemampuan generik atau tranferable skill sedangkan faktor keempat, kurikulum lama berdasarkan SK. Mendikbud No.056/U/1994 masih berbasis content. Keempat faktor di atas mendukung pengembangan perguruan tinggi dari model TCL ke SCL dan sesuai dengan empat pilar pendidikan, yaitu learning to know, learning to do, learning to be, dan learning to live together (Dewayani, 2006).

Pada model pembelajaran SCL, berarti mahasiswa harus didorong untuk memiliki motivasi dalam diri mereka sendiri kemudian berupaya keras mencapai kompentensi yang diinginkan. Hal ini bisa dilakukan dengan cara banyak berdiskusi, maka mahasiswa berani mengemukakan pendapat, belajar memecahkan masalah yang dihadapi dan tidak takut 
pada dosen. Harapannya dengan diterapkan sistem pembelajaran SCL adalah mahasiswa aktif dan kreatif, menyelesaikan tugas akhir dengan lancar/cepat, karena konsultasi pada dosen tidak punya rasa takut, dengan harapan mahasiswa dapat menyelesaikan studi dengan lancar dan tepat waktu sesuai dengan target atau bahkan bisa lebih cepat dari standar waktu masa studi. Selanjutnya mahasiswa setelah lulus diharapkan mampu berkompetisi di dunia kerja (Hadi, 2007). SCL atau Student Centered Learning merupakan pendekatan dalam pembelajaran yang memfasilitasi pembelajar untuk terlibat dalam proses experiential learnig.

Agar pembelajaran model SCL dapat diimplementasikan secara efektif dan efisien, maka perguruan tinggi juga mempunyai peranan dalam mengkaji kurikulum, program pembelajaran dan sistem penilaian hasil belajar yang mengacu pada SCL, membuat kebijakan tentang sosialisasi dan penerapan SCL di institusinya, menciptakan lingkungan belajar yang kondusif untuk terlaksananya SCL dengan menciptakan networking dengan dunia kerja, lembaga-lembaga

\section{METODE PENELITIAN}

Dilihat dari waktu penelitian rancangan penelitian yang digunakan adalah Cross Sectional karena pengukuran dan pengumpulan data hanya satu kali saja dan dilakukan pada saat itu juga serta peneliti tidak melakukan tindak lanjut. masyarakat, atau instansi yang terkait, membenahi pola pikir (mindset) pada dosen dan pengelola program pendidikan pada umumnya tentang pentingnya mengubah paradigma mengajar berorientasi pada dosen semata pada pola pembelajaran yang berorientasi pada mahasiswa yang dicirikan dengan adanya interaksi yang positif dan konstruktif antara dosen dan mahasiswa dalam membangun pengetahuan, melatih dan memberikan dukungan yang penuh kepada para dosen dalam menerapkan SCL dalam proses pembelajaran, memanfaatkan perencanaan pembelajaran yang berorientasi SCL, yang dikembangkan para dosen, dalam pengadaan sarana dan prasarana pendukung pembelajaran, dan menciptakan sistem yang memungkinkan dosen dan seluruh akademik dapat berkomunikasi dan berkoordinasi serta akses terhadap IT (information technology) (Ramdhani, 2006). Pemahaman peran dari ketiga elemen utama proses pembelajaran sebagaimana diuraikan di atas, akan mampu mendukung efektivitas metode-metode pembelajaran yang masuk dalam klasifikasi model pembelajaran SCL.

Jenis penelitian yang digunakan yaitu pendekatan Non-Eksperimental yakni penelitian yang tidak ada intervensi atau perlakuan.

Dalam penelitian ini variabel yang digunakan bivariet (dua) yaitu variabel independennya persepsi mahasiswa semester IV dan variabel dependennya IP (indeks prestasi). 
Sumber data pada penelitian ini data primer diperoleh dari lembar kuesioner yang dilakukan langsung kepada sasaran yakni mahasiswa semester IV. Setelah mendapat rekomendasi dari institusi, kemudian peneliti meminta ijin persetujuan

\begin{tabular}{|l|c|c|}
\hline \multicolumn{1}{|c|}{$\begin{array}{c}\text { IP } \\
\text { (Indeks } \\
\text { Prestasi) }\end{array}$} & $\begin{array}{c}\text { Frekuen } \\
\text { si }\end{array}$ & $\begin{array}{c}\text { Persenta } \\
\text { se }\end{array}$ \\
\hline $\begin{array}{l}\text { IP } \\
\text { Memuask } \\
\text { an }\end{array}$ & 33 & 31,3 \\
$\begin{array}{l}\text { IP kurang } \\
\text { memuaska } \\
\text { n }\end{array}$ & 15 & 68,7 \\
\hline Jumlah & $\mathbf{4 8}$ & $\mathbf{1 0 0}$ \\
\hline
\end{tabular}

untuk Pengambilan data dan untuk melakukan pendekatan kepada responden dengan memberikan penjelasan mengenai tujuan penelitian, untuk mendapatkan persetujuan kesediaan menjadi responden. Bila calon responden setuju menjadi responden penelitian, maka calon responden diminta untuk menandatangani lembar persetujuan menjadi responden penelitian dengan menggunakan informed consent. Kemudian peneliti memberikan lembar kuesioner kepada responden untuk di isi. Data sekunder dalam penelitian ini adalah data jumlah mahasiswa semester IV dan nilai IP (indeks prestasi) yang diperoleh dari dokumentasi KHS (kartu hasil studi) semester IV. Penelitian ini menggunakan data dengan cara analisis bivariet. Analisis ini dilakukan terhadap variabel-variabel penelitian melalui uji chi square, untuk memenuhi syarat uji chi square skala data ordinal di konfersi jadi data nominal pada variabel indeks prestasi dibuat kategori memuaskan dan kurang memuaskan

\section{HASIL}

Dalam bab ini peneliti akan menyajikan hasil penelitian dari pengumpulan data mengenai Hubungan Persepsi Mahasiswa Semester IV Tentang Metode Pembelajaran SCL (Student center learning) Terhadap IP (Indeks Prestasi) yang akan diuraikan sesuai dengan tujuan penelitian. Pada hasil penelitian ini dibagi dalam dua bagian yaitu data umum dan data khusus.

Data khusus dimulai dari Persepsi Mahasiswa Semester IV Tentang Metode Pembelajaran SCL (Student center learning), IP (indeks prestasi) mahasiswa semester IV dan mengetahui Hubungan Persepsi Mahasiswa Semester IV Tentang Metode Pembelajaran SCL (Student center learning) Terhadap IP (Indeks Prestasi).

A. Hasil Penelitian Data Khusus

1. Persepsi Mahasiswa Semester IV tentang Metode Pembelajaran SCL (Student Centered Learning)

Tabel 1.1 Distribusi frekuensi Persepsi Mahasiswa Semester IV Tentang Metode Pembelajaran SCL (Student Centered Learning). 


\begin{tabular}{|c|c|c|c|c|c|c|}
\hline & \multicolumn{7}{|c|}{ IP (indeks prestasi) } \\
\cline { 2 - 7 } $\begin{array}{c}\text { Persep } \\
\text { si } \\
\text { Mahasi } \\
\text { swa }\end{array}$ & \multicolumn{2}{|c|}{$\begin{array}{c}\text { Memuas } \\
\text { kan }\end{array}$} & \multicolumn{2}{|c|}{$\begin{array}{c}\text { IP } \\
\text { Kurang } \\
\text { memuas } \\
\text { kan }\end{array}$} & \multicolumn{2}{c|}{ Total } \\
\cline { 2 - 7 } & N & $\%$ & N & $\%$ & N & $\%$ \\
\hline $\begin{array}{c}\text { Positif } \\
\text { Negatif }\end{array}$ & 2 & 20 & 8 & 80 & 10 & 100 \\
\hline Total & 13 & 2 & 25 & 65,8 & 38 & 100 \\
\hline
\end{tabular}

Pada tabel 1.1 menunjukkan bahwa dari 48 mahasiswa semester IV mayoritas memiliki persepsi negatif tentang metode pembelajaran SCL (student centered learning) sebanyak $38(79,17 \%)$ mahasiswa.

2. IP (Indeks Prestasi)

Tabel 2.1 Distribusi frekuensi IP (Indeks Prestasi) mahasiswa semester IV.

Pada tabel 5.2 menunjukkan bahwa dari 48 mahasiswa semester IV mayoritas memiliki IP kurang memuaskan sebanyak $33(68,7 \%)$ mahasiswa.

B. Hasil Penelitian Data Khusus Berupa Tabulasi Silang dan Analisis Data dengan Menggunakan Uji Chi Square

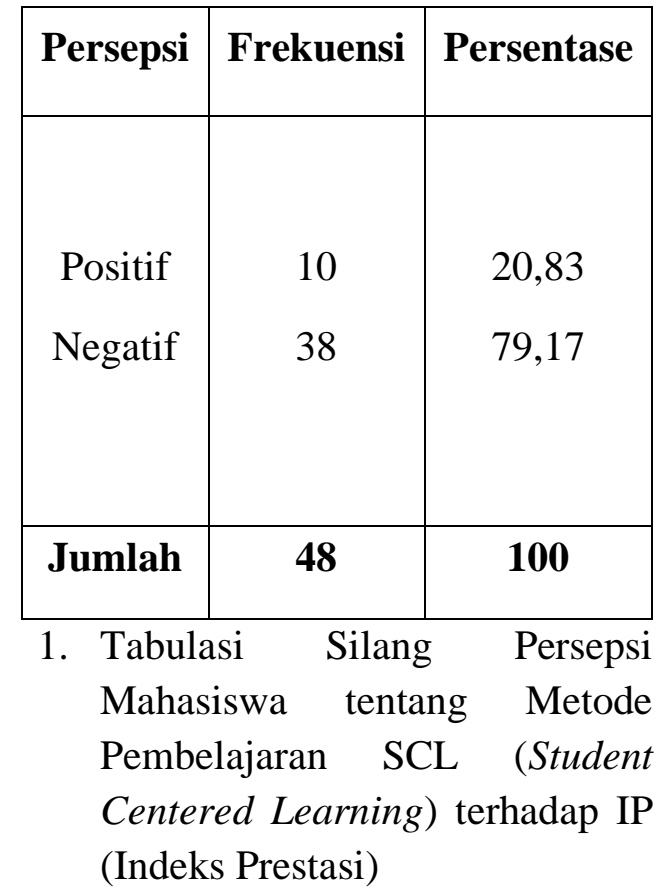

Tabel 1.1 Tabulasi silang persepsi mahasiswa tentang metode pembelajaran SCL (student centered learning) terhadap IP (indeks prestasi). Dari tabel diatas dapat diketahui bahwa persepsi mahasiswa yang positif dengan IP (indeks prestasi) kurang memuaskan sebanyak $8 \quad(80 \%)$ mahasiswa dibandingkan dengan mahasiswa yang memiliki IP (indeks prestasi) memuaskan sebanyak 2 (20\%) mahasiswa , sedangkan untuk persepsi mahasiswa yang negatif dengan IP (indeks prestasi) kurang memuaskan sebanyak $25 \quad(65,8 \%)$ mahasiswa dan untuk IP (indeks prestasi) memuasakan sebanyak 13 $(34,2 \%)$ mahasiswa.

2. Uji Chi Square Hubungan Persepsi Mahasiswa tentang Metode Pembelajaran SCL 
(Student Centered Learning) terhadap IP (Indeks Prestasi)

Berdasarkan hasil uji chi square pada tabel 4.4 didapatkan bahwa $\mathrm{P}=0,472$. Jika $\mathrm{P}<\alpha$, maka Ho ditolak dan jika $\mathrm{P}>\alpha$ maka Ho diterima. $\mathrm{P}=0,472$ dan $\alpha=0,05$. Maka pada uji chi square diatas menghasilkan $\mathrm{P}>\alpha$ $(0,472>0,05)$ maka $\mathrm{H}_{0}$ diterima dan $\mathrm{H}_{1}$ ditolak, sehingga dapat disimpulkan bahwa tidak ada hubungan antara persepsi mahasiswa tentang metode pembelajaran SCL (student centered learning) terhadap IP (indeks prestasi).

\section{PEMBAHASAN}

1. Persepsi Mahasiswa Semester IV tentang Metode Pembelajaran SCL (Student Centered Learning)

Menurut tabel 1.1 mayoritas mahasiswa semester IV berpersepsi Negatif tentang metode pembelajaran SCL (student centered learning) berjumlah $38(79,17 \%)$ mahasiswa.

Menurut (Sobur, 2009) faktor-faktor yang mempengaruhi persepsi yaitu ada 4 faktor, faktor yang pertama adalah Faktor fungsional merupakan dihasilkan dari kebutuhan, kegembiraan/suasana hati, pelayanan, dan pengalaman masa lalu seorang individu. Faktor yang kedua adalah faktor struktural merupakan faktor yang timbul atau dihasilkan dari bentuk stimulus dan efek-efek netral yang ditimbulkan dari sistem saraf individu. Faktor yang ketiga adalah faktor situasional merupakan Faktor yang berkaitan dengan bahasa non verbal. Petunjuk proksemik, petunjukan kinesik, petunjuk wajah, dan pertunjukan paralinguistik. Dan faktor yang terakhir adalah faktor personal merupakan faktor yang terdiri dari pengalaman, motivasi, dan kepribadian. Menurut (Herminta, 2008) Persepsi adalah proses yang digunakan individu dalam mengelolah dan menafsirkan kesan indra mereka dalam rangka memberikan makna kepada lingkungan mereka, meskipun demikian apa yang dipersepsikan seseorang dapat berbeda dari kenyataan obyektif. Menurut (Fajar, 2009) Suatu tindakan persepsi mensyaratkan kehadiran obyek eksternal untuk dapat ditangkap oleh indera. Dalam hal perspektif terhadap diri pribadi, kehadirannya sebagai obyek eksternal mungkin kurang nyata tetapi keberadaannya jelas dapat dirasakan, selain itu persepsi juga timbul karena adanya informasi untuk di interpretasikan. Informasi yang dimaksud di sini adalah segala sesuatu yang diperoleh melalui sensasi atau indera. Menurut (Yulifah, 2009) Persepsi merupakan pandangan personal terhadap suatu kejadian. Persepsi dibentuk oleh harapan dan pengalaman. Perbedaan persepsi dapat menghambat proses komunikasi.

Dari hasil penelitian didapat banyak mahasiswa semester IV berpersepsi negatif tentang metode pembelajaran SCL (student centered learning) berjumlah $38(79,17 \%)$ mahasiswa. 
Hal ini dikarenakan bahwa persepsi sesorang dipengaruhi oleh beberapa faktor yaitu faktor fungsional misalnya pada saat diberlakukannya metode pembelajaran SCL mereka belum siap dengan adanya perubahan yang mana dulu TCL sekarang menjadi SCL maka dapat membuat persepsi sesorang terhadap metode pembelajaran SCL negatif, yang kedua adalah faktor struktural merupakan suatu stimulus yang dihasilkan oleh sistem saraf individu misalnya stimulus yang didapat pada saat proses pembelajaran tidak sesuai dengan yang diharapkan maka juga bisa menyebabkan persepsi seseorang negatif terhadap metode pemebelajaran SCL negatif, faktor situasional misalnya pada saat itu situasinya kurang mendukung untuk diterapkan metode pembelajaran SCL sehingga secara tidak langsung dapat membuat persepsi sesorang menjadi negatif, dan yang terakhir adalah faktor personal misalnya seseorang yang pada dasarnya pasif yang apabila diterapkan sistem metode pembelajaran SCL yang dimana sesorang dituntut untuk aktif maka dia merasa tidak nyaman dan merasa disampingkan sehingga dapat menimbulkan persepsi yang negatif. Yang dimana keempat faktor tersebut mempengaruhi persepsi mahasiswa semester IV tentang metode pembelajaran SCL (student centered learning) apakah positif maupun negatif. Mahasiswa semester IV banyak yang berpersepsi negatif tentang penerapan metode pembelajaran SCL (student centered learning) ini dikarenakan mereka menganggap bahwa metode pembelajaran SCL membuat mereka tidak bisa bersantai karena banyak tugas yang diberikan oleh dosen dan para mahasiswa beranggapan bahwa tugas yang diberikan oleh dosen merupakan beban melainkan bukan suatu keharusan atau kewajiban dari seseorang mahasiswa. Tugas yang diberikan biasanya dalam bentuk kasus dan diselesaikan dengan kelompok masing-masing. Menurut mereka tugas kelompok tidak enak karena biasanya hanya beberapa orang saja yang mengerjakan, selain itu untuk menyelesaikannya mahasiswa harus melowongkan waktu untuk berkumpul bersama. Mereka beranggapan bahwa dosen tidak berperan sebagai fasilitator dan motivator karena dosen hanya suka memberi mereka tugas saja.

\section{IP (Indeks Prestasi)}

Menurut tabel 2.1 mayoritas mahasiswa semester IV memiliki IP kurang memuaskan sebanyak 33 $(68,75 \%)$ Mahasiswa.

Menurut (Anni, 2004) faktor-faktor yang mempengaruhi hasil belajar terbagi menjadi 2 yaitu faktor internal dan faktor eksternal. Faktor internal, yang mencakup aspek fisik, misalnya kesehatan organ tubuh, aspek psikis, misalnya intelektual, emosional, motivasi, dan aspek sosial, misalnya kemampuan bersosialisasi dengan lingkungan. Dan yang kedua adalah Faktor eksternal, misalnya variasi dan derajat kesulitan materi yang dipelajari, tempat belajar, iklim, 
suasana lingkungan, budaya belajar masyarakat dan sebagainya. Sedangkan menurut (Purwanto, 2004) faktor-faktor yang mempengaruhi hasil belajar adalah Faktor dalam, yaitu fisiologis seperti kondisi fisika dan panca indra serta psikologis yang menyangkut minat, tingkat kecerdasan, bakat, motivasi, dan kemampuan kognitif. Dan Faktor luar yaitu kurikulum, guru, sarana dan fasilitas serta manajemen yang berlaku di sekolah (tempat belajar) yang bersangkutan.

Dari hasil penelitian yang didapat mahasiswa semester IV banyak memiliki IP kurang memuaskan sebanyak $33(68,75 \%)$ Mahasiswa, jumlah tersebut membuktikan bahwa IP mahasiswa masih banyak dibawah rata-rata. Hal ini dikarenakan banyaknya faktor penyebab yang menyebabkan seseorang memiliki IP yang kurang yaitu bisa dari faktor internal maupun eksternal. Faktor internal dapat mencakup dari berbagai macam yaitu aspek fisik, misalnya kesehatan organ tubuh, kelengkapan atau kecacatan organ tubuh, dan lain-lain sehingga dapat menghambat proses belajarmengajar. Aspek psikis, misalnya intelektual atau kepintaran sesorang berbeda satu dengan yang lainnya, emosional atau emosi yang berubahubah, motivasi baik dari dalam diri sendiri maupun dari orang lain atau dari luar kurang yaitu motivasi untuk belajar dan menuntut ilmu, dan yang terakhir adalah aspek sosial, misalnya kemampuan bersosialisasi dengan lingkungan juga dapat menyebabkan hasil belajar kurang maksimal. Dan yang kedua adalah Faktor eksternal, misalnya variasi dan derajat kesulitan materi yang dipelajari berbeda-beda, tempat belajar yang menunjang seperti sarana dan prasarana, iklim, suasana lingkungan yang menyenangkan, budaya belajar masyarakat dan sebagainya, semunya itu dapat mempengaruhi rendahnya nilai IP yang dihasilkan atau mendapatkan IP dengan kategori kurang memuaskan.

\section{Tabulasi Silang Persepsi Mahasiswa tentang Metode Pembelajaran SCL (Student Centered Learning) terhadap IP (Indeks Prestasi)}

Menurut tabel 1.1 mayoritas mahasiswa semester IV mempunyai persepsi negatif dengan IP (Indeks Prestasi) kurang memuaskan sebanyak 25 (65,8 \%) mahasiswa.

Menurut (Mulyan, 2008) dapat di jelaskan bahwa makna merupakan jatungnya komunikasi dan persepsi itu mempertajam komunikasi. Persepsi merupakan inti dari komunikasi sebab jika persepsi tidak akurat, maka komunikasi tidak akan berajalan dengan secara efektif. Selain itu, akan menentukan kita memilih pesan dan mengabaikan pesan lain pastinya setiap orang memiliki persepsi yang berbeda. Menurut (Sunaryo, 2004) Persepsi dibedakan menjadi dua macam, yaitu External perception dan self perception. External perception yaitu persepsi yang terjadi karena adanya rangsangan yang datang dari luar diri 
individu. Sedangkan self perception yaitu persepsi yang terjadi karena adanya rangsangan yang berasal dari dalam diri Individu, dalam hal ini yang menjadi objek adalah dirinya sendiri.

Dari hasil penelitian yang didapat mahasiswa semester IV banyak yang mempunyai persepsi negatif terhadap SCL dengan IP (Indeks Prestasi) kurang memuaskan sebanyak 25 $(65,8 \%)$. Hal tersebut bisa terjadi apabila seseorang sudah mempunyai persepsi yang negatif maka akan susah untuk menerima suatu informasi. Persepsi merupakan inti dari komunikasi sebab jika persepsi tidak akurat, maka komunikasi tidak akan berajalan dengan secara efektif. Selain itu, akan menentukan kita memilih pesan dan mengabaikan pesan lain pastinya setiap orang memiliki persepsi yang berbeda. Perbedaan persepsi dapat menghambat proses komunikasi sehingga merupakan salah satu penyebab IP kurang maksimal. Mahasiswa banyak yang mempunyai IP kurang memuaskan ini bisa disebabkan oleh pola belajar yang tidak baik atau malas belajar yang dimana kalau belajar itu harus rutin dan terus-menerus, saat ujian tidak belajar, tidak ada motivasi untuk mendapatkan nilai baik atau tidak ada semangat untuk menuntut ilmu, ada rasa tidak kesukaan pada mata kuliah tertentu sehingga malas untuk belajar atau mengikuti perkuliahan, masingmasing orang mempunyai tingkat kepintaran yang berbeda, sering sakit sehingga jarang masuk kuliah dan ketinggalan pelajaran semua itu dapat menyebabkan mahasiswa mendapatkan nilai IP yang kurang memuaskan.

4. Hubungan Persepsi Mahasiswa tentang Metode Pembelajaran SCL (Student Centered Learning) terhadap IP (Indeks Prestasi)

Berdasarkan hasil uji chi square pada tabel 4.4 didapatkan bahwa $\mathrm{P}=0,472$. Jika $\mathrm{P}<\alpha$, maka Ho ditolak dan jika $\mathrm{P}>\alpha$ maka Ho diterima. $\mathrm{P}=0,472$ dan $\alpha=0,05$. Maka pada uji chi square diatas menghasilkan $\mathrm{P}>\alpha(0,472>0,05)$ maka $\mathrm{H}_{0}$ diterima dan $\mathrm{H}_{1}$ ditolak, sehingga dapat disimpulkan bahwa tidak ada hubungan antara persepsi mahasiswa tentang metode pembelajaran SCL (student centered learning) terhadap IP (indeks prestasi).

Meskipun angka berpersepsi negatif tinggi dan IP yang kurang memuaskan tinggi, namun hasil statistik analisa data menunjukkan tidak adanya hubungan antara persepsi mahasiswa tentang metode pembelajaran SCL (student centered learning) terhadap IP (indeks prestasi). Hal ini dapat dikarenakan masih ada sebagian mahasiswa yang berpersepsi negatif tetapi memiliki IP yang memuaskan dan ada juga mahasiswa berpersepsi positif tetapi memiliki IP yang kurang memuaskan.

\section{KESIMPULAN DAN SARAN}

Kesimpulan 
Mahasiswa semester IV mayoritas memiliki persepsi negatif Tentang Metode Pembelajaran SCL (Student center learning) sebanyak 38 $(79,17 \%)$ mahasiswa. Mahasiswa semester IV mayoritas memiliki IP (Indeks Prestasi) kurang memuaskan sebanyak $33(68,75 \%)$ mahasiswa. Tidak ada hubungan antara persepsi mahasiswa tentang metode pembelajaran SCL (student centered learning) terhadap IP (indeks prestasi).

\section{Saran}

Diharapkan penelitian ini dapat menabah kepustakaan bagi yang membutuhkan referensi dan dapat dijadikan kontribusi akademis dalam mengembangkan konsep atau teori tentang metode pembelajaran yang lebih efektif

Demi kepentingan ilmiah maka diharapkan ada kelanjutan dari penelitian ini sehingga menjadi lebih baik dan secara otomatis juga memberikan solusi yang terbaru mengenai masalah pendidikan.

\section{DAFTAR PUSTAKA}

Dewajani, Sylvi. 2006. "Student Centered Learning", Materi Lokakarya Peningkatan Kualitas Teknik Pembelajaran Student Center Learning. Yogyakarta: UGM
Fajar, 2009. Promosi Kesehatan dan

Ilmu Perilaku. Jakarta Rineka Cipta.

Hadi ,R,2007. Dari Teacher Centered Learning ke Student Centered Learning: Perubahan Metode Pembelajaran di Perguruan Tinggi. Insania, Vol.12, No. 3. hal. 408-419.

Purwanto, Ngalim. 2004. Psikologi Pendidikan. Jakarta. PT. Remaja Rosdakarya.

Sunaryo, 2004. Psikologi Untuk Keperawatan. Jakarta: PKBI Sobur, A, 2009. Psikologi Umum. CV Pustaka Setia: Bandung Yulifah, 2009. Tentang Persepsi. Bandung: Alfabeta 